\title{
Using Patterns-of-Participation Approach to Understand High School Mathematics Teachers' Classroom Practice in Saudi Arabia
}

\author{
Layla Alsalim ${ }^{1, *}$ \\ ${ }^{1}$ Department of Curriculum and Instruction, College of Education, Princess Nourah Bint Abdulrahman University; \\ Riyadh, Saudi Arabia \\ *Correspondence: Department of Curriculum and Instruction, College of Education, Princess Nourah Bint \\ Abdulrahman University; Riyadh, Saudi Arabia. Tel: 966-567-850-0001. E-mail: Laalsalim@pnu.edu.sa
}

Received: November 26, 2018

Accepted: January 10, 2019 Online Published: January 17, 2019

doi:10.5430/wje.v9n1p1

URL: https://doi.org/10.5430/wje.v9n1p1

\begin{abstract}
During the past decade, the Saudi Arabian education system has undergone major changes. Government agencies involved in education have introduced new policies, standards, programs, and curricula. The focus of this research is to describe and understand high school mathematics teachers' current practices in Saudi Arabia. This research includes three cases of teachers currently teaching high school mathematics in Saudi Arabia. Using the Patterns of Participation concept (PoP) as the main framework, I identified some of the significant practices, or figured worlds, from the teachers' sense of their practices. Some of the figured worlds that emerged are mathematics, the textbook, reform, and responsibility for students' achievement. Mathematics, as it has always been, remains an influential figured world for mathematics teachers. Reform and the textbook are becoming as influential because of the current changes in the education system in Saudi Arabia. While some participant teachers are developing a new understanding of what mathematics is and what it means to teach it, they also indicated that they are mostly still using traditional teaching strategies rather than reform teaching strategies
\end{abstract}

Keywords: patterns of participation; teacher; practice; mathematics

\section{Introduction}

Teaching is a complex practice that involves constant and dynamic interaction between teacher, students, subject matter, and much more. When education organizations implement reform initiatives, one of the main goals is often to change teachers' classroom practices. In the past, educators viewed changing the curriculum as an endeavour to change the content of instruction more than the teachers' classroom practices. However, most recent curricula reform has focused on promoting and implementing teacher practices that promote students' understanding of mathematics alongside changes in content (Cohen \& Ball, 1990; Tirosh \& Graeber, 2003).

Mathematics education reform has been the focus of researchers over the past several decades. Many researchers describe mathematics reform as movement away from a traditional approach or teacher-centered instruction towards a more student- centered or learner-centered approach. In a learner-centered practice, students are active participants in their learning. Teachers provide students with opportunities to investigate, communicate, and make connections within mathematics concepts and with the world around them (Ball, 1994; Simon, 1995; Boaler, 2002; NCTM, 1989, 1990, 2000; Ross et al., 2003; Smith \& Star, 2007).

Prior to 2007, the Saudi Arabian education system experienced very few changes. This was also true for mathematics teaching practices, which were very traditional. Teachers relied on traditional mathematics textbooks and focused on delivering mathematical content and knowledge (Al Sheki, 2011; Al Balawi \& Al Rajeh, 2012). Prior to the current reform, using the textbook was enough for teachers to have acceptable teaching practices Recent government initiatives intended to improve the quality and quantity of education in Saudi Arabia are evidence of the urgency for education reform, especially with the number of young people increasing. Government agencies involved in education have introduced new policies, standards, curricula and textbooks with the expectation that teachers will incorporate the changes seamlessly; however, they have failed to take into consideration existing teacher practices. Therefore, the 
purpose of this research is to describe and understand high school mathematics teachers' current practices in Saudi Arabia.

\subsection{Why Study Teachers' Practices}

Teaching is not simply a matter of being in classrooms and delivering lessons to students; teaching involves a complex set of practices that takes place both inside and outside the classroom (Bransford, Darling-Hammond, \& LePage, 2005). Teachers' practices include strategies used in their everyday professional activities. Teachers must work effectively with their students to incorporate and structure curricular materials and theoretical concepts into actual classroom practices. In order for teachers to offer an environment for effective learning, they must do more than merely stand in front of a classroom and lecture. Moreover, although teachers spend most of their school time in the classroom, classroom teaching is just one aspect of their profession (Bransford, Darling-Hammond, \& LePage, 2005).

Teachers recognize that teaching includes instructional planning, assessing students' learning, and interacting with students (Bransford, Darling-Hammond, \& LePage, 2005). Therefore, in their practices, teachers continue to learn and apply a variety of different approaches that incorporate different types of knowledge (Fishman \& Davis, 2006; Goos \& Geiger, 2010). Studying teacher practices can help researchers understands teachers' learning opportunities for teaching practices, which can have positive impact on students' learning experiences (Bransford, Darling-Hammond, $\&$ LePage, 2005).

Studying teachers' practices is important for understanding and improving educational processes. Generally, "teachers are the cornerstone of nearly all formal instructional system" (Fishman \& Davis, 2006, p. 535). Many researchers consider teachers as influential individuals in their classroom because the decisions they make affect all aspects of classroom instruction and learning (Cooney, 1994; Simon, 1995). They are also the most significant element in educational innovations (Fishman \& Davis, 2006). Hill, Rowan, and Ball (2005) noted teachers' practices structure students' learning environment and greatly impact student motivation and achievement. They view teachers as the main school-related factor affecting student achievement.

\section{Theoretical Framework}

In this research, Patterns of Participation (PoP) theory is used as the main framework. Skott $(2010,2011,2013,2014 \mathrm{a}$, 2014b) presents PoP as a framework that aims to understand the role of the teacher for emerging classroom practices. Instead of relying on a traditional approach to understanding classroom practices by analyzing teachers' beliefs, this framework applies a participatory approach to look for patterns in the participation of individual teachers in many social practices at the school and in the classroom. Skott's main motivation in developing the PoP framework was to overcome the conceptual and methodological problems of belief research (Skott, 2009, 2010).

Over the last 25 years, there has been a significant amount of research on teachers' beliefs (Skott, 2010). Many researchers support the view that the beliefs of students and teachers have a great influence on the way both behave in a school environment (McLeod, 1992; Thompson, 1992). As a result, numerous researchers have conducted studies on the crucial role of beliefs in learning and teaching mathematics. The studies assume that issues resulting from beliefs play a major role in mathematics learning and instruction (McLeod, 1992).

Scholars focusing on belief research assume that teachers' beliefs are a major determinant for teachers' practices in the classroom. As a result, researchers in this area argue that influencing teachers' beliefs could play a crucial role in changing teachers' classroom practices (Wilson \& Cooney, 2002; Lerman, 2002). Skott (2009, 2013, 2014a, 2014b) indicates that this research approach was, and continues to be, strongly built on the assumption that teachers' beliefs are a major barrier to educational change, and that research about teachers' beliefs has the potential to find solutions to "the problems of implementation of the new and more process-oriented approach to mathematics instruction" (2009, p. 28).

However, belief research has many unresolved issues and many conceptual and methodological challenges (Skott, 2010, 2011, 2013; Skott et al., 2011; Skott 2014a, Skott 2014b). One of the primary conceptual challenges researchers encounter when studying beliefs is the diverse meanings of the term (Pajares, 1992; McLeod \& McLeod, 2002; Skott, 2014a, 2014b). Pajares (1992) argues that to define beliefs is not clear-cut and is dependent on the definer; users of the word belief often use attitudes, judgements, opinions and perceptions, among others, synonymously. "Defining beliefs is at best a game of player's choice. They travel in disguise and often under alias [such as] attitudes, values, judgments, axioms, opinions, ideology, perceptions, conceptions, conceptual systems...” (Pajares, 1992, p. 309).

Moreover, Skott $(2014 \mathrm{a}, 2014 \mathrm{~b})$ explains four major aspects of the conceptual challenges of belief research. First, beliefs are used to explain a person's mental structure, "which are subjectively true for the person in question" (p. 6). 
Second, "there is an element of affect to beliefs. Beliefs then are value-laden and characterized by a certain degree of commitment" (Skott (2014a, p. 6). The third major aspect is the stability of beliefs. Beliefs are mostly treated as being a stable structure. People are supposed to have the same beliefs regardless of the situations they are encountering. In addition, people are not expected to change their beliefs unless they encounter a significant new experience. The last aspect is beliefs are expected to control people's actions, engagement and participation in different social settings. "To sum up, the notion of beliefs is used in the literature about mental reifications that are acquired on the basis of comprehensive, previous social experiences and that are characterised by considerable degrees of conviction, commitment, stability and impact" (Skott, 2014a, p. 6).

The conceptual challenges facing beliefs research have created some methodological challenges. The problem of having a clear definition to the concept of beliefs creates a challenge of how to operationalize it (Skott, 2014a, 2014b). Therefore, researchers have questioned the methodologies use for belief attribution. Those researchers imply that researchers and teachers may have different perceptions and understandings of the concept of belief (Speer, 2005). This methodological problem is due to the inherent difficulty of describing teachers' beliefs, which leads to the need to employ multiple sources and use a mix of methodologies when conducting a research. Skott (2014a) also states, "The methods used in the field do not provide access to what people really believe or at least not to beliefs that matter for the situation at hand" (p. 6). Lester (2002) also emphasizes the methodological challenges of studying teachers' beliefs. He indicates that researchers may be involved in a circular argument of inferring beliefs from the nature of mathematical activity while trying to explain the same activity with regard to a principle construct of beliefs.

The challenges and complexity associated with belief research has led some researchers, such as Skott (2009, 2010, 2011, 2013, 2014a, 2014b) and Gates (2006), to call for more social approaches to belief research. Gates (2006) indicates that there is a need to take a social approach when studying teacher belief systems because it will shift focus from cognitive constructs. A change towards sociological constructs will balance existing views about the nature and genesis of beliefs. Skott (2010) also supports this view; he takes a context-practice approach by adopting of Patterns of Participation framework, which he sees as providing a more coherent and dynamic understandings of teaching practices. Furthermore, this approach may help to resolve some of the conceptual and methodological problems of a belief-practice approach while maintaining an interest in the meta-issues that constitute the field of beliefs. The PoP framework challenges dominant traditional belief research by questioning the very notion of beliefs and its acquisitionist theoretical foundation (Skott, 2010).

\subsection{Patterns of Participation: Towards a More Social Approach for Understanding Teachers' Practices}

Understanding the relationship between individual and social features of human learning has generated an ongoing argument in research in mathematics education (Skott, 2013). Some researchers support the necessity of consistently using one family of theoretical frameworks. Researchers who advocate this approach, such as Sfard (2008), highlight the importance of the social character of individuals' meaning-making and emphasize the importance of participation in learning. On the other hand, researchers such as Cobb (1994), Cobb and Yackel (1996), and Lester (2005) suggest that embracing ideas from a variety of theoretical sources is useful to provide a better understanding and offer richer explanations. By following this approach, a coordination of cognitive and social perspectives on knowing and coming to know could be obtained (Cobb \& Yackel, 1996).

The social approach of research in mathematics education has progressively promoted the notion that practice is not only a personal individual matter; it is within a sociocultural context. Researchers must interpret practice relatively, between individuals and social settings. Although the relationships between individual and social factors of human functioning have generated much debate in mathematics education, it is mainly in relation to student learning (Skott, 2013). Therefore, PoP is a theoretical framework that aims to understand the relationships between teachers' practices and social factors. The PoP framework elaborates on the view that teachers' practices in classrooms are not simple expressions of their desire and personal resources; it also views their practices as adaptations to social conditions in which they work. As noted by Skott (2013), the "teacher contributes to classroom interaction by re-engaging in other past and present practices, possibly reinterpreting and transforming them in the process" (p. 548). The PoP framework presents a useful tool to understand the teachers' position for emerging classroom practices that takes into account the multiple perspectives of student learning in educational research.

\subsection{Patterns of Participation: Adopting Participationism as a Metaphor for Human Functioning}

In mathematics education, researchers have discussed extensively the acquisition metaphor and participation metaphor as two basic metaphors underlying theories of learning. Sfard (2008) compares the nature of mathematics learning using two different theories: the acquisitionists and the participationists. She explains that while acquisitionists view learning as the result of the learners' individual endeavour to arrive at a coherent understanding of the world, 
participationists' vision recognizes that learning arises essentially from one's attempt to make sense of other peoples' view of this world. Sfard (2008) points out that according to acquisitionist theory, learning mathematics can occur without the participation of others, but participationists view mathematics as a form of discourse (any form of communication) that requires learning to originate through communication with others and adjusting one's discursive ways to those of other people. In other words, participationists' theory indicates that mathematics learning starts through participation in collective mathematical discourses, exists in various learning environments (home, community, or school) and gradually increases knowledge of how to individualize the discourse as individuals communicate mathematically with themselves and others.

Skott (2010) claims that connections exist between the focus of belief research about individuals and the acquisitionist metaphor for learning in constructivism. While belief research contradicts the restricted view of understanding teaching and learning concerning cognitive aspects, the basic definitions and characteristics of the concept of beliefs indicate that it agrees with the constructivist emphasis on the individual. Although researchers mainly consider beliefs the result of experiences that consist of long-lasting engagement in social interaction, when beliefs are constructed, researchers usually consider them as completely individual constructs. Some participatory theoretical views challenge constructivism acquisitionist because there are a few exceptions to the principle that beliefs are entirely the property of the individual.

PoP is a theoretical framework developed in line with several other social approaches to research in mathematics education. It aims to develop a more coherent understanding of the teacher's role for learning and life in mathematics classrooms. This alternative framework emphasizes the emergent nature of classroom practices. To a considerable degree, PoP adopts participationism as a metaphor for human functioning more than mainstream belief research. Therefore, PoP draws on the work of participationism researchers, specifically Vygotsky (1980), Lave and Wenger(1991), and Sfard(2008).

The notions of practice and participation are basic constructs in the origins of PoP. The term practice in PoP holds the same meaning as when researchers use it in social practice theory, as a social phenomenon. Skott et al. (2011) consider practice as an outcome of individual and communal meaning-making and agency that emerges in the local social environment. "It is embedded in broader social situations, but the emphasis on emergence means that we regard it as an empirical question how and to what extent for instance a school culture, the students' family backgrounds, national or local educational regulations, or recommendations for reform play a role for the practices that evolve" (p. 32). This understanding of the concept of practice leads to the conclusion that teachers' practices are not directly linked to any individual in the school or classroom community. Teachers' practices in classrooms are results of their classroom interaction by re-engaging other past and present experiences, and reinterpreting and transforming these experiences in the process. A teacher's practice is influenced and bound together through re-engagement in other essential discourses and practices through the meaning they place on the social interaction itself.

PoP takes into account that a "teacher negotiates classroom practices by interpreting the students' and her own possible contributions to the interactions symbolically" (Skott, 2013, p. 550). PoP analyzes teachers' specific practices in relation to other classroom practices that teachers engage in simultaneously. The teacher also takes the attitude of individual and generalized others and relates it to practices generated from other social interactions such as interactions with other teachers, and from meetings with the parents or the school management.

Skott adopts Holland et al. (1998)'s notion of figured worlds to serve as an appropriate lens for the PoP framework. According to Holland et al. (1998) figured worlds are imagined communities that function dialectically and dialogically as if in worlds. They constitute sites of possibility that offer individuals the tools to impact their own behaviour within these worlds. They define figured worlds as "socially and culturally constructed realm[s] of interpretation in which particular characters and actors are recognized, significance is assigned to certain acts, and particular outcomes are valued over others" (p. 52). On the other hand, figured worlds are socially organized and reproduced phenomena that provide "a context of meaning and action in which social positions and social relationships are named and conducted" (Holland et al., 1998, p. 60). Figured worlds are formed upon the individual's co-constructed understanding through interaction with others rather than on innate, individual nature. Through figured worlds, individuals incorporate a system of interpretations drawn from their social interactions. Therefore, figured worlds are different from beliefs system, which are constructed mainly on an individual's feeling.

The PoP framework focus on exploring and identifying significant practices and figured worlds in which mathematics teachers participate and upon which they draw on. The PoP framework "suggests attempting to understand how teachers draw on and renegotiate their participation in a range of their past and present practices and figured world as they engage in classroom interaction" (Skott, 2014a, p. 21). 
As a framework, PoP directs the research questions, shapes the research design, and controls data gathering and analysis. The research questions for PoP include asking about the role of teacher's stories of themselves as professional in their classroom engagement, the impact of teachers' relation to educational discourses such as the reform adoption, and the connection between how teachers engage with mathematics in and outside classroom contexts. The questions are, however, dependent on the person-in-practice. In addition, the design of the research should, as much as possible, permit access to teachers' practices and figured worlds beyond the classroom. "The unit of analysis may then be described as the teacher-in-multiple-practices- and-figured worlds as they relate to classroom interaction" (Skott, 2013, p. 552).

\section{Method}

The focus of the study is to understand high school mathematics teachers' practices during the current reform movement in Saudi Arabia. A qualitative research methodology is the best and most appropriate approach for this study. According to Creswell (2013), qualitative research is described as "an inquiry process of understanding based on a distinct methodological approach to inquiry that explores a social or human problem. The researcher builds a complex, holistic picture, analyzes words, reports detailed views of participants, and conducts the study in a natural setting" (p. 300).

For this research study, I used a case study methodology to present three cases. Each case represents the experience of a female mathematics high school teacher in Saudi Arabia to develop a deep understanding of their teaching practices in current girls' high school classroom. Using case studies as a research method allows me to learn from the participants by describing and interpreting the meaning of their teaching experiences. Stake (1995) explains the main motivation and aim of using a case study methodology by saying:

The real business of case study is particularization, not generalization. We take a particular case and come to know it well, not primarily as to how it is different from others but what it is, what it does. There is emphasis on uniqueness, and that implies knowledge of others that the case is different from, but the first emphasis is on understanding the case itself (p. 8).

Every teacher participated in my research has her own unique experience, but by looking at each of their experiences individually and as a whole, I am able to gain a deeper understanding of the practices of teaching high school mathematics in Saudi Arabia.

\subsection{Participants}

Data presented in this study is about three teachers: Abeer, Noha, and Maram . The teachers represent different levels of experience and teach different grades in high schools. The following table presents some basic information about the participants.

Table 1. Basic Information about the Participants

\begin{tabular}{|c|c|c|c|c|}
\hline Participants & Degree & Years of experience & $\begin{array}{c}\text { Grade } \\
\text { currently } \\
\text { teaching }\end{array}$ & $\begin{array}{c}\text { Number of } \\
\text { lessons currently } \\
\text { teaching }\end{array}$ \\
\hline Abeer & $\begin{array}{l}\text { B.Ed specialization } \\
\text { in mathematics. }\end{array}$ & $\begin{array}{l}\text { Six years teaching high } \\
\text { school only. }\end{array}$ & $11 \& 12$ & $\begin{array}{l}24 \text { lessons per } \\
\text { week }\end{array}$ \\
\hline Noha & $\begin{array}{l}\text { B.Ed specialization } \\
\text { in mathematics }\end{array}$ & $\begin{array}{c}\text { Four years teaching } \\
\text { middle school and nine } \\
\text { years teaching high school } \\
\text { (13 years total). }\end{array}$ & $10 \& 11$ & $\begin{array}{l}22 \text { lessons per } \\
\text { week }\end{array}$ \\
\hline Maram & $\begin{array}{l}\text { BSc specialization } \\
\text { in mathematics }\end{array}$ & $\begin{array}{l}11 \text { years teaching high } \\
\text { school only. }\end{array}$ & 11 & $\begin{array}{l}18 \text { lessons per } \\
\text { week }\end{array}$ \\
\hline
\end{tabular}

\subsection{Data Sources}

I incorporated a triangulation of the data from a variety of resources including interviews, observations, and a review of written documents. In PoP, the main purpose of methodical triangulation "is not that it enables one to 'locate' or specify one and the same construct with greater accuracy. Quite the opposite, different methods provide at least some access to different social practices and figured worlds, which may turn out to be significant for the interpretation of 
the teacher's interaction with the students" (Skott, 2013, p. 557). Also, the collection of data from multiple sources offered a rich, thick description with several dimensions and realities offering deeper insight and improving the validity and reliability. This thick description includes information from transcripts of observations and interviews, field notes, coding of data, and memo writing (Creswell, 2018).

In my research, data is drawn from two primary sources and four minor sources. The two primary sources are interviews and classroom observations. The minor sources for data collection are data from informal observations of staff-room communication between the participant teachers and their colleagues, a copy of the teachers' lesson planning notebooks, some of their worksheets and test samples and the official mathematics textbooks used in high schools.

I considered interviews and classroom observations as primary sources because they were more useful in my analysis to identify and understand the significant practices or figured worlds in the participants' practices as mathematics teachers. Therefore, I mostly relied on these two sources for data analysis. The field notes prepared from the observations and the interviews were among the primary sources of the data. All the data I collected is in Arabic including the interviews, the observations and all the written documents I gathered from the teachers.

Data gathering for this research happened in two phases. For phase one, I gathered data over a six-week period. I conducted two interviews and attended sex lessons for each of the teachers participating in my research. For each teacher, I conducted the first interview before attending any of her classes. The second interview took place after I had attended four classes of that teacher. I transcribed every interview immediately after the interview was conducted. After the initial coding, I felt there was a need to meet with the teachers again to clarify some issues, and ask some additional questions. Since I was studying in Canada at that time, I couldn't travel back to Saudi Arabia to conduct phase two until seven months later when I had a three-week period to gather further data. During this phase, I conducted a third interview and attended two more classes for every teacher.

\subsubsection{Primary Sources of Data}

\subsubsection{Interviews}

Qualitative interviewing is a powerful tool that researchers can use to gather rich data. Through interviewing, the researcher can understand how participants describe and interpret their experiences, and the meaning they make of those experiences (Weiss, 1994). All of the interviews conducted for this research study were one-on-one and face-to-face semi-structured interviews. I interviewed every teacher three times. Every interview took between 50-60 minutes. The format of semi-structured interview is appropriate for finding depth of meaning and gaining insight and understanding of the teachers' experience. The semi-structured format of an interview allowed me to get detailed information in a style that has an informal nature and is slightly conversational. The informal nature of the interviews style offers the opportunity to understand thoroughly the answers provided (King \& Horrocks, 2010). The interview structure employs open-ended questions that are informal and engaging for the participant, while making them feel comfortable to express their point of view and speak their minds (Patton, 2002; King \& Horrocks, 2010).

Some of the questions I asked to interviewees. were structured to ensure the minimum necessary data from each participant. This structure guided the interview through the list of questions that I generated prior to meeting the participants (Weiss, 1994). However, some of the questions I asked were non-structured questions that emerged from the data as it developed during the interviews.

During the first interview, I started by asking the participants basic background questions about themselves such as years of experience, classes and grades have and currently teaching etc. as a way of warming up the participant. I asked the participants about their school and university experience and how they made the decision about what to study at university. Then I moved to more concrete questions about reform and the textbooks change. For the second interview, I asked them about everyday practices in relation to their profession. I tried to situate the question within a practice context; for example, I asked questions such as, "Walk me through the process you use to prepare for you lesson today?" and "Think about what you taught today; how would you describe the lesson?" I also asked questions related to the lessons I attended using stimulated recall technique. For the third interview, I asked questions to clarify some issues raised from the first and second interviews and asked any questions I missed during the first visit.

During the second and third interviews, I used the stimulated recall technique. The purpose of using this technique is to encourage teachers to reflect and elaborate on their views of mathematics teaching while referring to their actual classroom practices. Skott (2014b) suggests using stimulated recall technique to invite "teachers to think aloud about relevant classroom process" (p. 21). I applied this technique by playing a small part from the lessons I observed and asked the teachers to comment on what is happing in the audio recording. 
All interviews were audio-recorded and transcribed. I was also able to take some field notes during the interview. I tried to focus on things that may not come across on the recording when played back while transcribing such as the body language expressed by the interviewee. I focused on observing the participants' behaviour during the interview to include the emerging relationship between the participant and myself in my notes, as recommended by Charmaz (2006).

\subsubsection{Classroom Observations}

Observation is valuable during qualitative research because it allows the researcher to get direct access, perceptions, and embedded views into the examined phenomena, settings, and participants (Creswell, 2018). I visited and observed the participants in the classrooms where they taught. These observations provided me the opportunity to see the participants as they are teaching in their classrooms. I was able to see them being mathematics teachers through the experiences they have told me about, as well as through perceiving their experiences in the classrooms while they were happening.

I observed eight lessons for every participant. Observations lasted from 40 to 45 minutes, the duration of a complete mathematics class. During the observations, I did not participate in classroom activity in any way; I sat in a location that caused the least amount of disruption to the classroom environment, as requested by each teacher. I placed an audio recording at the front of the class to primarily capture the teacher's voice. During the observations, I took field notes to document the teachers' activities throughout the lesson. The notes were descriptive, focusing on recording and describing the teaching activities; however, after every lesson I wrote some reflective field notes to record my personal thoughts and insights about the lesson (Creswell, 2018).

\subsubsection{The Minor Data Sources}

The minor sources for data collection are a copy of the teachers' lesson planning notebooks, some of their worksheets and tests samples, the official mathematics textbooks used in high schools and data from informal observations of staff-room communication between the participant teachers and their colleagues.

The documents I received from the participants include a copy of their lesson planning notebooks and some of their worksheets and tests samples offer a source of text data for my research. As Creswell (2018) noted, these types of documents "provide the advantage of being in the language and words of the participants, who have usually given thoughtful attention to them" (p. 223). These documents revealed some insights and relevant information about the participant teachers' teaching strategies, the use of curriculum materials, and students' assessment

\subsection{Data Analysis}

The purpose of this data analysis is to present every case individually by adopting PoP to identify the significant practices or figured worlds of participant teachers and how they engage with these figured worlds. As recommended by Skott $(2013,2011)$, to overcome these challenges, I use techniques and procedures to analyze data inspired by Charmaz $(2000,2006)$ grounded theory approach including the use of coding schemes, constant comparisons, and memo writing. Since the data analysis process is the core of grounded theory, I use grounded theory as a method of data analysis techniques while disregarding the "objectivist connotations" that are usually affiliated with the theory (Skott, 2013, p. 552). As I mentioned before, I am using PoP as the main framework for my study; therefore, I am approaching the data with a theoretical perspective, which to some extent, guided the coding process. The way I engaged with the data was not as open as recommended by grounded theory approach; I adopted the grounded theory coding technique for data analyses without adopting the philosophy behind the grounded theory. Grounded theory approach recommends not conducting any pre-research literature review nor relaying on any theoretical framework for data collection and analysis which is not the approach I used in this research.

According to Charmaz $(2000,2006)$, coding helps the researcher to engage with the data and ask questions that help to gain new perspectives with regard to the phenomena under examination. Coding in grounded theory consists of many different stages. In this research, I applied the two fundamental and basic stages of coding identified by Charmaz (2000, 2006); the open or initial coding and the focus or selective coding. Through the coding process, I was able to organize, group and reflect on the data. The process includes isolating patterns and categorizing the data to identify practices and figured worlds that are significant for the participant teachers and how they engage with these figured worlds.

I used a constant comparative process of data analysis throughout the coding process. This continuous process of producing and testing codes is fundamental in the grounded theory approach to ensure validity and reliability. Constant comparison is a way of maintaining a connection between the codes and the data. Every time I generated a new code, I compared it to the other data I coded to check consistency in applying the codes. At this stage, coding involved a progression toward saturation by looking for more instances that represent the same code and continuing 
to look for new information about the code until the concept or the code is saturated. The constant comparison process eventually led to saturation (Charmaz, 2000, 2006).

\section{Discussion}

\subsection{Abeer's Case}

Abeer has 30-33 students in every class. Her students sit in groups that do not remain static; she changes who is in each group every week. She forms new groups every Sunday (the first day of the school day in Saudi Arabia) by assigning students randomly. The textbook is always a part of her lesson. She usually starts her lesson with an activity that students do within their groups. Abeer rarely assigns her students homework, but when she does, her students know that they are not required to work on it at home.

After six years of teaching, the data generated about Abeer suggest that there are five significant practices or figured worlds to Abeer's sense of her practices as a mathematics teacher. These figured worlds are mathematics, the textbook, the reform, students' achievement, and her relationship with other teachers in her school.

\subsubsection{Mathematics}

Abeer's sense of her practices has developed from her experiences as a student and a as teacher of mathematics. Abeer tries to create a learning environment that is different from her own experience learning mathematics in school. "My mathematics class is not like my own experiences in school; we had to sit in rows, quietly, and work individually on long algorithms exactly like the teacher demonstrated". As a student, teachers told her learning mathematics is about finding the right answer to a problem. However, her notion of mathematics learning as a teacher is quite different. "I always knew that learning mathematics has more to it than finding the right answer".

In Abeer's classroom, effective communication is vital as both a learning process and an outcome. Sharing ideas and clarifying understanding is important in the communication process to help students build meaning of the mathematics concepts. Abeer's students know that even if there is one right answer to a problem, the way they go about finding the answer or the way they explain the answer is very valued in her classroom.

In her classroom, Abeer often invites her students to think of multiple approaches to solving mathematical problems because, as she indicated, it is very important to student learning of the mathematical concepts. Having students look for multiples ways of finding solutions and using multiple strategies provides Abeer with more opportunities to encourage her students to talk about their work and explain how they reached a solution.

\subsubsection{The Textbook}

Abeer has a strong appreciation for the new textbooks she is currently using in her teaching. Abeer uses the textbook as a tool to reflect on her practice. She stated that when she plans her lessons, and before she chooses a particular part from the textbook to use in her lesson, she asks herself, "What do I actually want to get out of this? What do I need my students to take away from this? How can I add to this to enrich students' learning experience? By answering these questions, I can imagine different scenarios". It is evident that Abeer engages deeply with the textbook during her planning for the lesson phase.

In her classroom, the textbook has an active presence. Abeer often invites her students to engage with the textbook. At the beginning of the lesson, she asks the students to read the parts of the lesson including previously covered skills and concepts, learning outcome of the lesson, and the major mathematical vocabulary used in the lesson. She gives them few minutes to discuss what they read in their groups. Then, she asks them to read the purpose of the lesson section, which presents information usually related to real life situations and sometimes requires the students to answer questions that follow the information. She usually discusses this part with the students and this discussion leads to the introduction of the main concept of the lesson

\subsubsection{The Reform}

Abeer is very enthusiastic about the current reform movement in Saudi Arabia. Her enthusiasm shows from her involvement in any professional development activities offered to her. She indicated, "most teachers don't like to participate in any activity related to professional development. For me personally, I am always willing to do so; I always make sure to tell the school principle and the school inspector that I am always ready for these kinds of activities". For Abeer, these activities provide her the opportunity to find new ideas, meet different teachers, and talk about mathematics teaching. 
For Abeer, the new mathematics curriculum created a new language to talk about mathematics teaching and learning. For example, teachers started talking about learning strategies such as cooperative learning, and flipped classroom. Abeer learned about these teaching strategies from the workshop she attended and from her inspector. Using learning strategies has become a big part of Abeer's every day planning process. She learns about effective ways of engaging these strategies in her class from her own experience by reflecting on her own practices.

Reform for Abeer means change. Abeer re-defined her role as teacher in the classroom after she was inspired from the reform ideas. When she talks about reform, she usually explains how the current reform movement has changed some aspects of her practice. Abeer described the first two years of her teaching career as being very traditional. "I was the person who had the mathematics and my job was simply to present what I know in the class". In her current classroom, Abeer draws on the message of the reform by giving her students more control over their own learning. She tries not to be the person with total authority all the time.

\subsubsection{Abeer's Relationship with other Techers in her School}

Abeer appreciates her experience working at her school. She is dedicated to the development of her school. She realizes the importance of a school community to create a positive learning environment for everyone. She indicated that schools are for not only sitting and learning for students; "everyone who works at this school learns from this experience". Abeer values communication with other teachers in the school and considers it an important source for her personal learning experience as teacher.

At her school, Abeer meets with other mathematics teachers every week or two to discuss issues related to students and school activities, but they also discuss issues related to mathematics teaching. Abeer and the other teachers do not design specific lessons together at these meetings, but they do share ideas and express their challenges in relation to teaching certain mathematics concepts. "I remember before I started teaching the trigonometry unit, I asked other teachers lots of questions and received some good ideas".

\subsubsection{Students' Achievement}

In the interviews, Abeer appears strongly committed to her students' achievement. Sharing students' main interest and understanding their biggest concerns is significant to her philosophies of her role as a high school mathematics teacher. For Abeer, teachers must meet the needs and address the concerns of their students. Abeer constantly engages with her students' emotional state of being under pressure to achieve in high school and then move on to college. The effort Abeer makes to support her students as they go through this tough experience is strongly related to her mathematics teaching. She expressed that students need to struggle to understand the mathematical concept; that this struggle would contribute to their achievement. "I play a significant role in how my students perform, I know that, and I am trying to give my students more control of the learning situation. I sometimes let them struggle to figure it out by themselves".

\subsection{Noha's Case}

Noha has 35-37 students in each class. In her classroom, students are usually quiet and calm, sitting in neat rows of two tables that face the front of the classroom. Normally, Noha starts her lesson by checking students' daily homework. She then reviews previous material. The classroom environment emphasizes getting work done. Noha plans her lessons every day and she makes sure to follow the plan very carefully. A measure of time on task indicates that the lesson is going very well and that students are doing what they are supposed to do in her class.

After thirteen years of teaching, the data generated about Noha suggest that there are five significant practices or figured worlds to Noha's sense of her practices as a mathematics teacher. These figured worlds are mathematics, the textbook vs the notebook, the reform, students' achievement, and voluntary work.

\subsubsection{Mathematics}

According to Noha, mathematics is a body of knowledge centered on specific concepts, and learning these concepts means knowing how to use them. For Noha, mathematics is all about doing; if you are able to do mathematics, then you know mathematics. She explained,

I see it as a body of knowledge we use in order to solve problems. Or you could say it's a tool that enables people to do things to get answers. The main components of mathematics' knowledge are things like a set of rules and formulas and a set of methods and procedures that allow us to find out the correct answers. You need to know what is the method or procedure that goes with every rule or formula.

Noha reported that she usually gives her students a lot of practice during class time. While her students work on the exercises, she moves around the classroom and provides students with direction about how to do the exercises. At this time, Noha's job is "to let them (students) know what they really have to put down". She explained that moving around 
provides her with a good sense of what the students are doing. Noha's students usually do not have many difficulties doing the exercises because when she is presenting the material on the board, she usually models exercise, so that students are prepared to work a similar one without her assistance.

According to Noha, a basic part of understanding mathematics involves memorization and repetitive practice. She clarified why memorization plays an important role in mathematical understanding by saying,

Some facts in mathematics need merely to be accepted as true and memorized, I can't explain some mathematics to my students in a way that they really understand. Maybe some people would not agree with my view, but I really see that there is a place for memorization of basic facts in mathematics learning.

However, she also added that memorization and being able to remember is not the ultimate goal in mathematics. She noted "most often in a mathematics classroom, students start with rote memorization. They should be able to gradually come to understanding by practicing".

Noha argued that although her teaching style is traditional, her approach plays an irreplaceable role in helping all students, regardless of their level of ability and learning style, to gain high level of conceptual understanding of mathematics and acquire strong mathematics problem-solving and reasoning skills. Her teaching approach focuses on three aspects: first, memorization of facts, rules and formulas; second, repetitive drills and practice of basic computation; and third, procedural skills practice and training. This approach, according to Noha, helps students to build a strong foundation of basic mathematics knowledge and skills, such as a deep understanding of mathematical concepts and fluency in using different mathematical procedures and methods. Students with such a foundation of basic mathematics knowledge and skills have the ability to do problem solving and reasoning.

\subsubsection{The Textbook vs the Notebook}

One notable practice in Noha's classroom is the absence of the textbook. Neither Noha nor her students use the textbook during the lesson. Noha explained her history of using the official textbook in her classroom by saying, "during my first year of teaching, I based much of my classroom activities on the textbook. In my second year, I used very little from it. Finally, in my third year, I got rid of it altogether and I haven't used the textbook during my lessons since. I started to rely on the notebook I design". After using the textbook as a main source for her practices for two years, Noha realized the textbook's deficiencies and substituted with an alternate version of the textbook. "The textbook failed to arouse my students' interest and keep them on track".

Noha designs a notebook each year to use with the students in her classroom. This notebook replaces the textbook. During the summer, when schools are closed, she plans her notebook. She organizes the notebook by chapters and lessons based on how they appear in the official textbook. Every lesson in her notebook starts with an empty line for students to write the title and date. Then there is an empty rectangle for students to use to write the main definition, theory or formulas after Noha writes them on the board. The last part for each lesson within the notebook contains a written example and unsolved exercise. Noha takes some of the exercises included in the notebook from the textbook while others she creates. At the beginning of the school year, Noha photocopies the notebook and distributes one to each of her students. Students rely on their notebooks entirely during the lessons, when they study, and for all their homework.

According to Noha, the notebook provides learning situations that guarantee keeping students engaged in learning activities during the lesson. She added, "Without a textbook, I can create lessons that engage students by relating mathematics to their needs. Lessons become clearer when I present the topic in an organized way, using a language that my students understand. Noha talked about her notebook very proudly and she does not intend to change this aspect of her teaching practices. She revealed that before the introduction of the new textbooks, the school inspector used to praise her for organizing and designing the notebook, however, after the introduction of the new textbooks the inspector asked her to stop using the notebook and start using the new textbook in her classroom.

Noha described the new textbooks as "balloons" looking full from the outside, but actually empty on the inside. She indicated that the new mathematics textbooks came with a new "advertised" perspective on mathematics teaching. It promotes mathematics instruction that allows deep conceptual understanding to take place in the classroom and provides opportunities for students to answer their own questions by investigating meaningful real-world tasks that employ different mathematical concepts into one problem. This advertisement in ,Noha's opinion, is not successful since they do not explain how a teacher can create this environment in her classroom. 


\subsubsection{The Reform}

Over several years, the school inspectors recognized Noha as an excellent teacher of mathematics because she represented the culturally accepted values of effective mathematics instruction. However, after the reform movement started, inspectors no longer appreciated some of her teaching practices. Noha indicated that when the reform movement started, especially with the introduction of the new textbooks, the school inspector told her she needed to reconsider her role as a mathematics teacher with regard to student learning and choosing mathematical activities. The school inspector also asked Noha to stop using the notebook in her classroom and to mainly use the new textbook for her classroom activities.

Noha complained that the reform curriculum materials, including the new textbooks, new teacher guide and the circulated notes of recommendations that teachers receive regularly from the Ministry of Education, do not prescribe or describe practices for teachers, but rather offer new visions of mathematics teaching practices. She noted, "according to the new vision, I am not supposed to be a source of knowledge, I am supposed to be a facilitator to help students develop their own knowledge. When I asked the inspector how I am supposed to do that, she said you need to let your students read from the textbook and try to learn by themselves. I simply don't agree with that view".

Noha explained that her role in the classroom is more valuable than the textbook. Her students consider her the main source of information because she knows them more the textbook does. Her role as a teacher involves understanding what her students know and what they need to know, and providing the environment for them to learn.

Noha described her teaching practices as being realistic. She stated, "You may consider my teaching model as being old school, which assumes that students essentially need to learn mathematics facts, however, I consider my teaching model as being realistic, providing students with what they need". She is convinced that her students are used to learning this way. According to her, her "realistic" way of teaching represents the culture of mathematics teaching and learning in Saudi Arabia and changing this culture in high school would create confusion and chaos, which students cannot handle. If the chaos happens, no one would be happy, including students, parents, school principals and even the school inspector.

\subsubsection{Students' Achievement}

According to Noha, there is a strong connection between successful and effective teaching and student achievements. Noha indicated that teaching must lead to improvement in students' academic performance; students' achievement is a measure of successful and effective teaching. She stated, "Student achievement is always the result of successful mathematics teaching. A teacher can never be considered successful if her students' achievement is low". She argues that to be successful, teachers should make a tangible impact on student achievement.

Student achievement appears to be the main goal of Noha's job as a mathematics teacher. In her practices, she relies mainly on two sources to evaluate student achievement, written tests and homework. She indicated that written tests are the main official evaluation method used in high school. She added, "In reality, students' learning experience in high school is mainly evaluated based on how well they do on tests. Students encounter different types of written tests (such as) quizzes, final, midterm, and standardized tests". She argued that educators have yet to come up with other reliable and effective ways to evaluate and assess student achievement. Besides the midterm and final exams, Noha gives her students a quiz at the end of every chapter. The end of the chapter quiz helps her assess the effectiveness of her instruction, as well as students' understanding of the concepts taught. Noha also explained that she does not support weekly testing because it destroys students' interest and motivation to study for tests.

Noha's expressed that she not only worries about her students' ability to succeed on school tests, she voiced unease regarding her students' abilities on standardized tests. She explained that while teachers are not required to provide any preparation help to students to succeed on standardized tests, she understands that her students want to achieve high scores on all types of exams. Therefore, she considers it part of her job to help prepare her students, especially for the General Aptitude Test (GAT).

\subsubsection{Voluntary Work}

Noha is a very active teacher. She is willing to do any work that could benefit students. She has no problem volunteering to do extra work even if not related to mathematics teaching. She explained, "I continue to volunteer in my school whenever there's a chance. Only few teachers in my school do volunteer work. All I want is to help create a more positive and productive school environment for all students". Noha revealed that most teachers at her school never give their time beyond the school day in any way and never consider doing any extra-curricular activities. 
A major part of Noha's volunteer work is designing and conducting free workshops for students at her school. Noha is one of few teachers in the district who conducts such workshops. The workshops focus on offering students skills and knowledge to help them score better on the GAT test. The workshops are open to all grade 11 and 12 students attending her school, not only the students in her classes. She offers this workshop twice a year; however, to minimize the number to students attending every workshop, students can attend only one workshop a year. Noha is not happy that some private institutes are trying to take advantage of the importance of this test and offer paid courses to teach students skills they learn at school.

Noha's finds that the nature of the GAT test requires her to train students to quickly and efficiently obtain answers; therefore, her instructions during the workshops tend to be procedure-oriented. She mentioned that she mostly trains her students to perform mathematical procedures that enable them to find answers to problems according to set rules. She explains that procedure-oriented instruction helps students to do well on tests, especially on the purely procedural parts of the test. According to Noha, the workshops help students feel more confident about doing the real test by becoming more familiar with its format.

\subsection{Maram's Case}

Maram is a high school teacher with eleven years of experience teaching high school. She is currently working at a high school in Al Khobar city located in the Eastern Province of the Kingdom of Saudi Arabia. She graduated with a Bachelor of Science degree with a specialization in mathematics. She does not have a degree in education; she has never taken any university education courses. After she graduated from university, she started teaching in a private school. She worked there for three years and she taught grades 10 to 12 . After that, she received an offer to teach in a public high school. She has been teaching in the public high school for eight years.

After eleven years of teaching, the data generated about Maram suggests that there are five significant practices or figured worlds to Maram's sense of her practices as a mathematics teacher. These figured worlds are mathematics, the textbook, the reform, students' achievement, and social network engagement.

\subsubsection{Mathematics}

Maram is very passionate about mathematics. She expressed her love for mathematics as a subject by saying, "As far back as I can remember, I have always loved mathematics. It is just something I enjoy. When I was a student at school, mathematics classes made me happy and I was relaxed in mathematics classes because I was doing something that makes sense to me".

Although Maram loves mathematics as a subject, she does not consider that main objective of her job as making her students love mathematics; she sees her job as making her students do mathematics. For Maram, teaching mathematics is about helping students built a strong understanding of mathematical concepts and practice mathematical procedures. According to her, the best way to learn mathematics is to encourage students to talk about mathematical concepts, explain their thinking process and do as many exercises as they can. She stated, "Practicing mathematics problems is a major part of learning mathematics. You can't learn to do mathematics without actually doing it a lot".

In Maram's classroom, the central goal of learning mathematics is for students to acquire the ability to apply their understanding of mathematical concepts to successfully solve problems. Although Maram evaluates her students based on content knowledge and not the effort they make, she stated that the more effort students put into the class work, the more likely they are to understand the mathematical content.

According to Maram, most of her students do not expect mathematics to be meaningful and make sense. Students are mostly content working with mathematical symbols and doing routine problems without ever grasping a real understanding of the problem. Most students perceive their roles mainly as acquirers who memorize formulas and rules and apply them repeatedly to similar problems.

According to Maram, strong students work to gain the knowledge and understand the material; they do not expect the teacher to do the work for them. These students usually have a strong mathematical foundation. Weak students, she finds, do not try hard enough to gain knowledge and they usually come to class with a poor mathematical background. Maram clarified that when she plans her lessons, she does not target one type of student, "strong" or "weak"; rather, she tries to use the "teaching to the middle" approach. She said, "Mainly, the approach I use is intended to offer instructional environments that support all my students on a daily basis for the sake of improving their foundation in mathematics". She admits that her teaching practice may not support the strong students to reach their full potential, but it could help the weak students to improve. 


\subsubsection{The Reform}

Current reform ideas in education remind Maram of the teacher she wanted to be when she started her teaching career. When she began teaching, she was determined to be a "non-traditional mathematics teacher", meaning a teacher who does not rely on the traditional lecture format of teaching. However, Maram considers her approach to mathematics teaching to be more on the traditional side. "I don't consider myself far from traditional teaching; most of the time I am traditional and present mathematics as facts and procedures, but I am willing to learn to do new things". She implied that she feels she is under pressure to be a good teacher. When I asked her to explain to me her view of a good teacher, she replied that a good teacher is the one who has a positive impact on student understanding, quality of learning, and student achievement.

Generally, Maram supports reform and articulated clearly that changing how teachers teach mathematics in schools is a necessary step. She supports reform recommendations regarding concrete exploration and meaningful representation of mathematical concepts. However, she finds some reform ideas too challenging and hard to translate into practices. She explained that making a shift in the classroom from focusing on procedural to conceptual learning and incorporating problem solving strategies to be extremely challenging for teachers. She finds that reform recommendations and new curriculum materials provide teachers with visions and do not offer explanations about how to transfer these visions into practices.

Maram also finds reform recommendations to be misleading, sometimes providing teachers with mixed messages about best and effective practices. She explained that reform focuses on ensuring that high school students are equipped for university. According to Maram, most parents, high school students, and teachers interrupt "preparing students for university" to help students to achieve higher grades. She stated,

In recent years, there is too much emphasis on preparing students for university. This emphasis forces teachers to adopt what I call teaching for entering university practice or teaching for the tests; [...]it is the practice that focus on doing routine problems and never having a proper understanding of the principles behind it. Perhaps it is fair to say that with this practice students can be successful in the short-term, doing well in tests, but in the long run, we are not actually helping them.

\subsubsection{The Textbook}

Maram expressed that before the introduction of the new textbooks, she was very excited about using different textbooks in her teaching. She finds that the new textbooks are generally better than the old ones at providing more opportunities for student engagement and participation. She likes that the new textbooks offer different levels of exercises that aim to develop mathematical problem solving and communication skills. She understands that the purpose of introducing the new textbooks is to encourage teachers to develop learning environments where their students have more time and room to reflect, discuss and investigate on their own. While she understands the vision of the new textbooks about what school mathematics should be, she still admits that mathematics in her classroom and in all her colleagues' classrooms "Is still generally taught using lecturing, whole class teaching, and regular testing".

Maram explained the reason why the new textbooks did not have the expected effect in her teaching practices could be due to the lack of support and preparation she received during their implantations. She expressed the complaint explicitly that the Ministry of Education did not put enough consideration into teachers' preparation of the use of the new textbooks. She implied that teachers were anticipating great support and professional development related to the new textbooks based on the Ministry of Education's manner of promoting the books.

Maram also talked about one aspect of the new textbooks that was not available in the old textbooks, making mathematics relevant to students' lives. She explained that although most lessons in the new textbooks have a section that relate the mathematical concept presented in the lesson to everyday life, Maram thinks that the new textbooks are not successful in making mathematics relevant to students lives. As a teacher, she finds making mathematics relevant to students' lives in high school is a very difficult task to achieve and, according to her, this is a fundamental reason for weak mathematics performance and motivation among high school students.

From her experience teaching with the old and new textbooks, Maram explained that she has learned that any textbook is merely as good as the teacher who uses it. While during her first years of teaching, she would follow the textbook entirely without even thinking about making any changes, now she understands that "The textbook is just a tool". She elaborated "[the textbook is] possibly a very important tool, but still a tool that I can use the way I find appropriate; ...there is no complete and perfect textbook; not the old one and not the new one". When planning her lessons, she considers the textbook as a guide, not a mandate for instruction; sometimes she follows the structure of the lesson presented in the textbook and sometimes she creates her own instruction. 


\subsubsection{Students' Achievement}

Maram explained that the main goal of high school mathematics teachers is to create a supportive environment where students can learn the necessary concepts for academic achievement. However, Maram finds that for most mathematics teachers this view of academic achievement does not go beyond the classroom and the written tests given to students. She understands students' achievement in a way that is different from how other teachers, and students, understand. She indicated that most teachers and students limit student achievement to their grades. "Teachers and students are not concerned with learning as much as they are concerned with achieving higher scores". In her opinion, the grading system used in schools, which is mainly based on written tests, does not reflect or communicate the level of actual academic progress or achievement that a student has developed during her time in school.

Maram also stated that teachers usually evaluate their teaching practices based on their students' grades. This practice leads teachers to focus on increasing their students' grades by teaching for the test. Maram blamed reform recommendations for not trying to adjust teachers' view about students' grades and academic achievement. She also claimed that some reform changes, such as introducing standardized tests, have emphasized the culture of testing in schools. She explained that introducing standardized testing in the Saudi education system has created a milieu that prevents teachers and students from valuing the importance of deep understanding of mathematics. Maram does not provide any type of training for her students to prepare for taking standardized tests such as the GAT test because she does not support the educational purpose of the tests. She also stressed the importance of adjusting the common view of students' academic achievement in order to make a real change in how teachers teach in schools. "New reform recommendations did not come with new ways to assess students' achievement rather than testing. We can't change how we teach our students if we don't change how we evaluate them. It is all related".

\subsubsection{Social Network Engagement}

Maram is very active on social media, especially on Twitter. She is a social media enthusiast with a passion for sharing ideas about mathematics and mathematics teaching. She uses Twitter to interact with others who share the same interests. She described her social media interaction, especially on Twitter, as her best hobby. She likes to post mathematics problems and get people's responses. She discusses their ideas about the problems she posts, corrects their answers and finally provides the right answer. According to Maram, this interaction helps her to learn more about the thinking process when engaging with mathematics. She enjoys responding to the questions people ask and the comments they make.

In her Twitter bio, she identifies herself as a person who loves mathematics and does not mention that she is a mathematics teacher. She stated, "I didn't want to describe myself in my Twitter bio as a mathematics teacher because my Twitter reflects me as a person not merely as a teacher; of course being a teacher is part of who I am, but it is not all of who I am". She indicated that she mainly uses Twitter to "Share the love of mathematics with others" and do "Fun mathematics stuff without being restricted to an official school curriculum". She gets most of the problems she posts from different recourses though mostly online. It is very rare that she uses some of these problems with her students in her classroom. The reason, she explained, is there is not enough time to cover all the curriculum material and do more extra activities. Although some of her students follow her on Twitter, they rarely engage with her online or try to solve any of the problems she posts.

According to Maram, her social media interaction makes her feel that she is not working in isolation. She described her connections in Twitter networks as sources of learning new things related to mathematics teaching. Sometimes she uses Twitter as a resource to compare classroom teaching techniques and learning styles and finds new ideas for lesson plans. Her social media interaction also helps to keep her in touch about issues regarding education in Saudi Arabia. "On Twitter, people usually discuss new regulations and policies coming from the Ministry of Education or the school district".

\section{Results}

All three teachers in this study have had difficulty interpreting reform recommendations and transferring them into practice. Moreover, they all reported struggling with changing their teaching practices. However, each of them expressed a different kind of struggle. Abeer completely supports the changes the current reform movement, though she did express that she was experiencing struggles with implementing the changes in her classroom. She explains the struggles she faces stems from her constant search for new ideas and new ways to implement change in her classroom. However, Noha suggests that she rejects the proposed changes from the Ministry of Education. Noha's main struggle with change comes her impression that changing her practices is compulsory and she has no choice, but to make 
changes. Therefore, she has fallen back into her comfort zone in her teaching practices. She is content with her professional practices and refuses to make any changes to it. Maram shows that there is a need to change school mathematics, but she finds most reform ideas too confusing, making it very challenging to implement change into her practices. Maram supports reform ideas in education, but at the same time, is struggling to adopt reform-oriented teaching. It is clear from Maram's case that there is a problem of the inconsistency between her positive reactions towards change and the fact that she is not able to bring effective change into her classrooms.

While Abeer is the only teacher who seems confident in her students' knowledge and abilities to learn, and has no problem to challenge her students, the other teachers express their worry that students may not have sufficient background knowledge or the ability to learn using a new approach. Noha argues that although her teaching style is traditional, her approach helps students of all abilities and learning styles acquire strong mathematical skills. She justifies that in high school, the mathematical content is getting harder and more abstract and if teachers try to teach mathematics as a subject of figuring things out or making sense of things, the result will be confusion and chaos, which students cannot handle. Maram also seems unsure that changing her teaching approach would help students learn. Her worst fear is wasting students' time trying to do something new and it does not work.

All teachers rely on the textbook in their teaching practices. However, each one of them has a different relationship with the textbook and a different approach to using it. In Abeer's classroom, the textbook has an active presence; she often invites her students to engage with it. The textbook shares her teaching philosophy; mathematics learning is not only rote rules and procedures, but also an exploration, investigation, and deep understanding of mathematical concepts. For Maram, the textbook is the primary source of information for deciding how she presents mathematical content. However, the textbook does not have a prominent position in her classroom. Maram approaches the way she uses the new textbooks cautiously, looking for ways it fits her students' needs and abilities. She has her way to personalize the textbook material to fit more with her students' needs. In Noha's case, the textbook has a unique status. In her classroom, the official mathematics textbook is never used. Instead of the textbook, Noha designs a notebook each year that she and her students use during the lessons. This notebook replaces the official textbook in her classroom. Noha uses the textbook to help her design her notebook; she uses the textbook as a guide to identify and order the topics and as a source for some exercises. In general, Noha finds that forcing teachers to rely mainly on one specific textbook in their teaching undermines the teacher's professional judgment regarding appropriate mathematical activities that meet the needs of all students.

\section{Conclusion}

While recognizing that we can never gain a complete understanding of another's experiences, Pop as a framework, offers a fair picture of the participant teachers' experience and an increased understating of their practices. The PoP framework helped to see how participant teachers are different in their practices even though they share many commonalities, such as using the same textbook. Also, it is important to clarify that I am not claiming that the figured worlds I identified for every case are the only figured worlds that contribute to the teachers' sense of their practice as mathematics teachers.

Three figured worlds appeared for each of the participant teachers, mathematics, textbooks, and reform. Through participation in these figured worlds, teachers can re-conceptualize their practices and adjust how they understand themselves as individuals and as members of their communities. These figured worlds work in a very complex system where they could support, and sometimes restrict, one another as every teacher contributes to classroom practice (Skott, 2013). Even though these figured worlds are significant to all participant teachers, every teacher engaged in these figured worlds differently, as explained in chapter five.

In looking at all of these cases, it becomes clear that mathematics, as it has always been, remains an influential figured world for mathematics teachers. Reform and the textbook are becoming as influential because of the current changes in education system in Saudi Arabia. While some participants' teachers are developing, a new understanding of what mathematics is and what it means to teach it, participant teachers also indicated that they are mostly still using traditional teaching strategies rather than reform teaching strategies.

The participating teachers are at very different places in their engagement with reform. They each have different degrees of engagement with reform and each one is trying to make sense of reform in terms of their own experience and practice. The new textbook for participant teachers represents the most important reform effort. They identified the new textbooks as a potential vehicle for helping teachers develop more reform-oriented practices. However, the textbook, as a figured world, means different things to different teachers. The textbook for some teachers presents only 
the mathematical knowledge, but for other teachers, the textbook is more than that. It presents a new way of teaching mathematics.

\section{References}

Al Balawi, A., \& Al Rajeh, N. (2012). The reality of mathematics teachers' professional development in Saudi Arabia (in Arabic). The Journal of Saudi Association for Education \& Psychology GESTEN, 38, 43-78.

Al Kathiri, S. (2014). Preparatory year: First year experience. The Saudi Journal of Higher Education, 11, 65-72.

Al Sheki, H. (2011). Towards an integrated strategy to design training programs for mathematics teachers in Saudi Arabia (in Arabic). Ajman Journal of Studies and Research, 10(1), 23-73.

Al-Abdulkareem, R., \& Hentschke, G. C. (2014). Textbooks and Constructivist Pedagogy in Saudi Arabian School Classrooms. Journal of Curriculum and Teaching, 3(2), 13-24. https://doi.org/10.5430/jct.v3n2p13

Alamri, M. (2011). Higher education in Saudi Arabia. Journal of Higher Education Theory and Practice, 11(4), 88-91.

Alaqeeli, A. (2014). The Preparatory Year: Global Perspectives \& Local Practices. The Saudi Journal of Higher Education, 11, 45-64.

Al-Dosary, A. S., Rahman, S. M., \& Shahid, M. (2005). An integrated approach to combat unemployment in the Saudi labor market. Journal of Societal \& Social Policy, 4(2), 1-18.

Alharbi, F. (2014). The development of curriculum for girls in Saudi Arabia. Creative Education, 5, 2021-2026. https://doi.org/10.4236/ce.2014.524226

Alissa, A. (2009). Educational reform in Saudi Arabia (in Arabic). Beirut, Lebanon: Alsaqi publishing house.

Almaraee, M. (2003). Improving competencies of mathematics teachers' use of technology at colleges of education in Saudi Arabia (CESA) (Doctoral dissertation). Available from ProQuest Dissertations and Theses database. (UMI No. 2003. 3097633).

AlMunajjed, M. (1997). Women in Saudi Arabia Today. United States: St. Martins Press. https://doi.org/10.1057/9780230373105

AlMunajjed, M. (2009). Women's education in Saudi Arabia: The way forward. New York: Booz \& Company Inc.

Alotabi, K. (2014). Student assessment strategies in Saudi Arabia: A case study of pre-and post-classroom practices. Literacy Information and Computer Education Journal, 3(1), 1758-1763. https://doi.org/10.20533/licej.2040.2589.2014.0234

AlSadan, I. A. (2000). Educational assessment in Saudi Arabian schools. Assessment in Education, 7(1), 143-155. https://doi.org/10.1080/713613320

Al-Salloom, H. (1991). History of educational movement in the Kingdom of Saudi Arabia. Washington, D.C: International Graphics.

Alyami, R. (2014). Educational reform in the Kingdom of Saudi Arabia: Tatweer schools as a unit of development. Literacy Information and Computer Education Journal (LICEJ), 5(2), 1515-1524. https://doi.org/10.20533/licej.2040.2589.2014.0202

AlZaid, A. M. (1990). Education in Saudi Arabia: A model with difference (In Arabic). Jeddah, S.A.: Saudi Publishing \& Distributing House Book.

Atkinson, R., \& Geiser, S. (2009). Reflections on a century of college admissions tests. Educational Researcher, 38(9), 665-676. https://doi.org/10.3102/0013189X09351981

Atkinson, R. (2001). Standardized tests and access to American universities. The 2001 Robert H. Atwell Distinguished Lecture, American Council on Education, Washington, DC. Retrieved July 7, 2017 from http://escholarship.org/uc/item/6182126z\#page-2

Atkinson, R. (2004). Achievement versus aptitude in college admission. In R. Zwick (Ed.), Rethinking the SAT: The future of standardized testing in university admissions (pp. 15-24). Retrieved July 4,2017 from http://ckrntandfebooks.etailer.dpsl.net.proxy.lib.sfu.ca/home/html/moreinfo.asp?isbn=0203463935

Ball, D. (1990). Reflections and Deflections of Policy: The Case of Carol Turner. Educational Evaluation and Policy Analysis, 12(3), 247-259. https://doi.org/10.3102/01623737012003247 
Ball, D. B. (1994). Developing mathematical reform: What don't we know about teacher learning - but would make good working hypotheses? Paper presented at the Teacher Enhancement in Mathematics K-6 (pp. 77-112). Arlington, VA.

Ball, D. L., \& Cohen, D. K. (1996). Reform by the book: What is-or might be-the role of curriculum materials in teacher learning and instructional reform? Educational Researcher, 25(9), 6-14.

Ball, D. L., \& Feiman-Nemser, S. (1988). Using textbooks and teacher's guides: A dilemma for beginning teachers and teacher educators. Curriculum Inquiry, 18(4), 401-423. https://doi.org/10.1080/03626784.1988.11076050

Ball, D. L., Thames, M. H., \& Phelps, G. (2008). Content knowledge for teaching: What makes it special? Journal of Teacher Education, 59(5), 389-407. https://doi.org/10.1177/0022487108324554

Battista, M. T., \& Clements, D. H. (2000). Mathematics curriculum development as a scientific endeavor. In A. E. Kelly \& R. A. Lesh (Eds.), Handbook of research design in mathematics and science education (pp. 737-760). Mahwah, NJ: Lawrence Erlbaum Associates

Blumer, H. (1969). Symbolic interactionism: Perspective and method. Berkeley: University of Los Angeles Press.

Boaler, J. (1999). Participation, knowledge and beliefs: A community perspective on mathematics learning. Educational Studies in Mathematics, 40, 259-281. https://doi.org/10.1023/A:1003880012282

Boaler, J. (2002). Learning from teaching: Exploring the relationship between reform curriculum and equity. Journal for Research in Mathematics Education, 33(4), 239-258. https://doi.org/10.2307/749740

Boaler. J. (2000). Introduction: Intricacies of knowledge, practice, and theory. In J. Boaler (Ed.), Multiple perspectives on mathematics teaching and learning, (pp. 1-18). Westport, CT: Ablex.

Bowen, G.A. (2009). Document analysis as a qualitative research method. Qualitative research journal, 9(2), 27-40. https://doi.org/10.3316/QRJ0902027

Bozarth, J. (2008). The usefulness of Wenger's framework in understanding a community of practice (Doctoral dissertation). Available from ProQuest Dissertations and Theses database. (304536838).

Bransford, Darling-Hammond \& LePage. (2005). Introduction. In Darling-Hammond, L., \& Bransford, J. (Eds.), Preparing Teachers for a Changing World: What Teachers Should Learn and Be Able To Do. (pp. 1-39). San Francisco: Jossey-Bass.

Briggs, D. (2009). Preparation for college admission exams. National Association for College Admission Counselling. $\begin{array}{llll}\text { Retrieved June } & 19, & 2017 & \text { from }\end{array}$ http://www.nacacnet.org/research/PublicationsResources/Marketplace/Documents/TestPrepDiscussionPaper.pdf

Calderhead, J. (1981). Stimulated recall: A method for research on teaching. The British Journal of Educational Psychology, 51, 211-217. https://doi.org/10.1111/j.2044-8279.1981.tb02474.x

Capraro, M.M., An, S.A., Ma, T., Chavez, A., \& Harbaugh, A. (2012) An investigation of preservice teachers' use of guess and check in solving a semi open-ended mathematics problem. The Journal of Mathematical Behavior, 31(1), 1-162. https://doi.org/10.1016/j.jmathb.2011.10.002

Charmaz, K. (2000). Grounded theory: Objectivist and constructivist methods. In N. K. Denzin \& Y. Lincoln (Eds.), Handbook of qualitative research (2nd ed.) pp. 509-535). Thousand Oaks, CA: SAGE.

Charmaz, K. (2006). Constructing grounded theory: A practical guide through qualitative analysis. London: Sage.

Cobb, P., \& Yackel, E. (1996). Constructivist and sociocultural perspectives in the context of developmental research. Educational Psychologist, 31(3/4), 175-190. https://doi.org/10.1080/00461520.1996.9653265

Cobb, P. (1994). Where is the mind? Constructivist and sociocultural perspectives on mathematical development. Educational Researcher, 23(7), 13-20. https://doi.org/10.3102/0013189X023007013

Cohen, D. K., \& Ball, D. L. (1990). Policy and practice: An overview. Educational Evaluation and Policy Analysis, 12(3), 233-239. https://doi.org/10.3102/01623737012003233

Cooney, T. J. (1994). Research and teacher education: In search of common ground. Journal for Research in Mathematics Education, 25, 608-636. https://doi.org/10.2307/749575

Creswell, J. W. (2013). Qualitative inquiry and research design: Choosing among five designs (2nd ed.). Thousand Oaks, CA: Sage.

Creswell, J. W. (2018). Educational research: Planning, conducting, and evaluating quantitative and qualitative 
research (6th ed.). Boston, MA: Pearson.

Fishman, B., \& Davis, E. (2006). Teacher learning research and the learning sciences. In R. K. Sawyer (Ed.), The Cambridge Handbook of the Learning Sciences (pp. 535-550). New York: Cambridge University Press.

Gates, P. (2006). Going beyond belief systems: Exploring a model for the social influence on mathematics teacher beliefs. Educational Studies in Mathematics, 63(3), 347-369. https://doi.org/10.1007/s10649-005-9007-z

Goos, M., \& Geiger, V. (2010). Theoretical perspectives on mathematics teacher change. Journal of Mathematics Teacher Education, 13(6), 499-507. https://doi.org/10.1007/s10857-010-9166-4

Hill, H.C., Rowan, B., \& Ball, D.L. (2005). Effects of teachers' mathematical knowledge for teaching on student achievement. American Educational Research Journal, 42(2), 371-406. https://doi.org/10.3102/00028312042002371

Holland, D., Skinner, D., Lachicotte, W, Jr., \& Cain, C. (1998). Identity and agency in cultural worlds. Cambridge, MA: Harvard University Press.

King, N., \& Horrocks, C. (2010). Interviews in qualitative research. London: Sage.

Lave, J., \& Wenger, E. (1991). Situated learning: legitimate peripheral participation. Cambridge, Cambridge University Press. https://doi.org/10.1017/CBO9780511815355

Lave, J. (1996) Teaching, as Learning, in practice. Mind, Culture \& Activity, 3(3), 149-164. https://doi.org/10.1207/s15327884mca0303 2

Lerman, S. (2002). Situating research on mathematics teachers' beliefs and on change. In G. C. Leder, E. Pehkonen, \& G. To“rner (Eds.), Beliefs: A hidden variable in mathematics education? (pp. 233-243). Dordrecht, The Netherlands: Kluwer Academic Publishers

Lester, F. K. (2002). Implications for research on students' beliefs for classroom practice. In G. C. Leder, E. Pehkonen, \& G. Torner (Eds.), Beliefs: A hidden variable in mathematics education? (pp. 345-353). Dordrecht: Kluwer.

McLeod, D. (1992). Research on the affect in mathematics education: A reconceptualization. In D. A. Grouws (ed.), Handbook of Research on Mathematics Teaching and Learning, (pp. 575-596). New York: Macmillan.

McLeod, D. B., \& McLeod, S. H. (2002). Synthesis-Beliefs and mathematics education: Implications for learning, teaching, and research. In G. C. Leder, E. Pehkonen \& G. Torner (Eds.), Beliefs: A hidden variable in mathematics education? (pp. 115-123). Dordrecht, The Netherlands: Kluwer Academic Publishers.

Ministry of Education. (2015). The General Director of Curricula in the Ministry of Education. Retrieved May 19, 2017 from https://www.moe.gov.sa/ar/PublicEducation/ResidentsAndVisitors/Pages/TheGeneralPrinciples.aspx

National Council of Teachers of Mathematics. (2000). Principles and standards for school mathematics. Reston, VA: Author.

Packer, M. J., \& Goicoechea, J. (2000). Sociocultural and constructivist theories of learning: Ontology, not just epistemology. Educational Psychologist, 35(4), 227-241. https://doi.org/10.1207/S15326985EP3504_02

Pajares, M. F. (1992). Teachers' Beliefs and Educational Research: Cleaning Up a Messy Construct. Review of Educational Research, 62(3), 307-332. https://doi.org/10.3102/00346543062003307

Patton, M.Q. (2002). Qualitative Research and Evaluation Methods (3rd ed.). Thousand Oaks, CA: Sage.

Petrou, M., \& Goulding, M. (2011). Conceptualising Teachers' Mathematical Knowledge in Teaching. In T., Rowland \& K., Ruthven (Eds.), Mathematical Knowledge in Teaching (pp. 9-25). NY: Springer. https://doi.org/10.1007/978-90-481-9766-8_2

Ross, J. A., McDougall, D., Hogaboam-Gray, A., \& LeSage, A. (2003). A survey measuring elementary teachers' implementation of standards-based mathematics teaching. Journal for Research in Mathematics Education, 34(4), 344-363. https://doi.org/10.2307/30034787

Rubin, H.J., \& Rubin, I.S. (2012) Qualitative interviewing: The art of hearing data (3rd ed.). Sage Publications, Thousand Oaks.

Sfard, A. (2001). There is more to discourse than meets the ears: Looking at thinking as communicating to learn more about mathematical learning. Educational Studies in Mathematics, 46(1), 13-57. https://doi.org/10.1023/A:1014097416157

Sfard, A. (2008). Thinking as communicating: Human development, the growth of discourses, and mathematizing. 
Cambridge, U.K.: Cambridge University Press. https://doi.org/10.1017/CBO9780511499944

Simon, M. A. (1995). Reconstructing mathematics pedagogy from a constructivist perspective. Journal for Research in Mathematics Education, 26(2), 114-145. https://doi.org/10.2307/749205

Skott, J. (2009). Contextualising the notion of belief enactment. Journal of Mathematics Teacher Education, 12(1), 27-46. https://doi.org/10.1007/s10857-008-9093-9

Skott, J. (2010). Shifting the direction of belief research: From beliefs to patterns of participation. In M.F. Pinto \& T.F. Kawasaki (Eds.), Proceedings of the 34th Conference of the International Group for the Psychology of Mathematics Education, 4, (pp. 193-200). Belo Horizonte, Brazil: PME

Skott, J. (2011). Beliefs vs. patterns of participation - towards coherence in understanding the role the teacher. In B. Roesken \& M. Casper (Eds.), Proceedings of the 17th Conference of Mathematical Views, (pp. 211-220). Bochum, Germany: MAVI.

Skott, J. (2013). Understanding the role of the teacher in emerging classroom practices: searching for patterns of participation. ZDM Mathematics Education, 45(4), 547-559. https://doi.org/10.1007/s11858-013-0500-z

Skott, J. (2014a). Towards a participatory approach to 'beliefs' in mathematics education. In B. Pepin \& B. Roesken-Winter (Eds.), From Beliefs to Dynamic Affect Systems in Mathematics Education. Exploring a Mosaic of Relationships and Interactions (pp. 3-23). Switzerland: Springer.

Skott, J. (2014b). The promises, problems and prospects of research on teachers' beliefs. In Fives, H., \& Gill, M G., (Eds.), International handbook of research on teachers' beliefs (pp. 13-30). New York: Routledge.

Skott, J., Moeskær Larsen, D., \& Hellsten Østergaard, C. (2011). From beliefs to patterns of participation - shifting the research perspective on teachers. Nordic Studies in Mathematics Education, 16(1-2), 29-55.

Smith, J. P., \& Star, J. R. (2007). Expanding the notion of impact of K-12 standards based mathematics and reform calculus programs. Journal for Research in Mathematics Education, 38(1), 3-34.

Speer, N. (2005). Issues of methods and theory in the study of mathematics teachers' professed and attributed beliefs. Educational studies in mathematics, 58(3), 361-391. https://doi.org/10.1007/s10649-005-2745-0

Stake, R. (1995). The art of case study research. Thousand Oaks, CA: Sage.

Thompson, A. (1992). Teachers' beliefs and conceptions: A synthesis of research. In D. A. Grouws (Ed.), Handbook of Research on Mathematics Teaching and Learning (pp. 127-146). New York: Macmillan.

Tirosh, D., \& Graeber, A. (2003). Challenging and changing mathematics teaching classroom practices. In A. Bishop, M. Clements, C. Kietel, J. Kilpatrick, \& F. Leung (Eds.), Second international handbook of mathematics education (pp. 643-688). Dordrecht, the Netherlands: Kluwer Academic Publishers. https://doi.org/10.1007/978-94-010-0273-8_22

Vygotsky, L. S. (1980). Mind in Society: The Development of Higher Psychological Processes. Cambridge, MA: Harvard University Press.

Weiss, R. S. (1994). Learning from strangers: The art and method of qualitative interview studies. New York: The Free Press.

Wilson, S., \& Cooney, T. (2002). Mathematics teacher change and development. In G. C. Leder, E. Pehkonen, \& G. To"rner (Eds.), Beliefs: A hidden variable in mathematics education? (pp. 127-147). Dordrecht, The Netherlands: Kluwer Academic Publishers. 